\title{
THE ETYMOLOGY OF THE
CHARACTER WEI 危 Jingjing Chen
}

$I^{\mathrm{N}}$ $\mathrm{N}$ THE EARLIEST FORM of Chinese writing - oracle bone inscriptions from the second millennium BCE - we find the graph $\{$. It was used to denote an empty vessel that was easy to overturn and, by extension, connoted a lack of stability. In jade seals of the Warring States period (475-221 BCE), this graph evolved into a clearer compound ideograph, $\mathcal{U}$. Scholars in the Song dynasty (960-1279 CE) identified this as xian 仚 'a man', ren 人 'on top of a mountain', and shan 山 'in imminent danger of falling'. The character xian 仚 was also considered interchangeable with the character xian 仙, denoting a man climbing a mountain but which came to refer to an immortal being.
The meaning of the graph continued to develop; by the Qin dynasty (221-206 BCE), 众 had become the character for 'crisis', 危. Two radicals - semantic indicators of a Chinese character - helped transform the original graph. They were jie $p$, signifying possible dangers to people on the mountains, and chang $\Gamma$, indicating the height of the mountains and the objects on top of them. The graph of jie $P$, with etymological roots in the concept of kneeling, has two main meanings, both of which denote dangers related to military affairs. As a verb, jie $\mathrm{p}$ signifies 'to moderate and to rule'; its secondary meaning is a noun, meaning 'military credentials'. Through the 
introduction of the radical of jie $P$, the sense of 'danger', 'precipitousness', and 'crisis' for the basic meaning of wei was reinforced.

The component chang literally means 'rooftop'. With the introduction of chang, wei came to describe objects on high, including those on high mountains and in the sky.

As a corollary, wei also came to describe objects such as buildings on top of mountains, including Buddhist or Daoist temples and shrines. Under the roof, the radical $P$ also has the meaning of worship and praying on one's knees. Astrology developed in the late Warring States period and the Qin and Han dynasties, and, in a dictionary of the Han dynasty (206 BCE-220 CE), we find that wei could also refer to the 'lunar lodge' or constellation known in Western tradition as Aquarius, which was believed to be the celestial complement of the earthly state of $Q i$.

During the reign of the first Qin emperor, a standardised system of written script was adopted throughout the empire and was continued over subsequent centuries. The character wei 危 became the standard. Its two basic meanings stabilised as well: bein Written in the style of writing known as small-seal script, wei 危 was often used interchangeably with the near-homophone wei 衛, meaning 'to defend' or 'to guard' or, as a noun, 'military guards'. Its meaning now encompassed notions of physical sickness, warfare and political challenges, including challenges to high-ranking officials engaged in military affairs with political opponents or rival states, while also describing those objects on high.

The great Tang dynasty poet $\mathrm{Li}$ Bai 李白 (701-762 CE) used wei to describe a Buddhist temple on the summit of a mountain where he once spent the night:

Here it is night: I stay at the Summit Temple.

Here I can touch the starts with my hand.

I dare not speak aloud in the silence.

For fear of disturbing the dwellers of Heaven.

危樓高百尺，手可摘星辰。

不敢高聲語, 恐敬天上人。 一一李白《夜宿山寺》

The Summit Temple serves as a bridge or place of mediation between the earthly and heavenly worlds; wei here serves to link humans and deities. 
Wei appears in a number of political aphorisms, in which the word draws on the meanings of danger and height. In Confucius's warning to the ruler of $\mathrm{Lu}$ 魯, given during the turbulent spring and autumn, he contrasted wei with an 安, meaning stable, safe, and secure:

[T]he land is not fruitful nor society prosperous, the people are hungry and cold, education and nurture neglected, social morals and customs disordered, and the people scattered. This is what we mean when we say wei. 地而不繁殖, 財物不蕃, 萬民複興寒, 敎訓不行, 風俗淫倅, 人民流散, 日危.

Referring to both basic meanings of the word, a Han text, meanwhile, advised rulers to

be lofty but not arrogant, so as to dwell on high without danger [wei]. Be frugal and circumspect, to achieve fullness without overspill. Dwell on high without danger [wei], and nobility shall be long maintained. 在上不驕, 高而不危, 制節謹度, 霂 而不溢, 高而不危, 所以長守貴也。
Similar messages were repeated or rephrased in many subsequent political texts on social norms, administration and ceremonial rites. During the Three Kingdoms period that followed the Han - a time of division and wei - the great strategist Zhuge Liang 诸葛亮 (181-234 CE) famously described how his home state of Shu, in present-day Sichuan, had come under threat (see image on p.8). Zhuge combined wei with ji 急 'urgent' to refer to existential danger: Shu was at war with Wei 魏 (a different wei), which was militarily stronger. The ruler of Shu, Zhuge Liang's master, had just passed away. As Zhuge wrote:

The late emperor was taken from us before he could finish his life's work, the restoration of the Han. The [old Han] empire is divided in three, Yizhou [modern Sichuan] is war-worn and under duress, and our life and very survival is under imminent threat [weiji].

帝創業未半而中道崩殂, 今天下三 分, 益州疲敝, 誠危急存亡之秋也.

Zhuge's words resonated in the turbulence and division of the twentieth century. When 


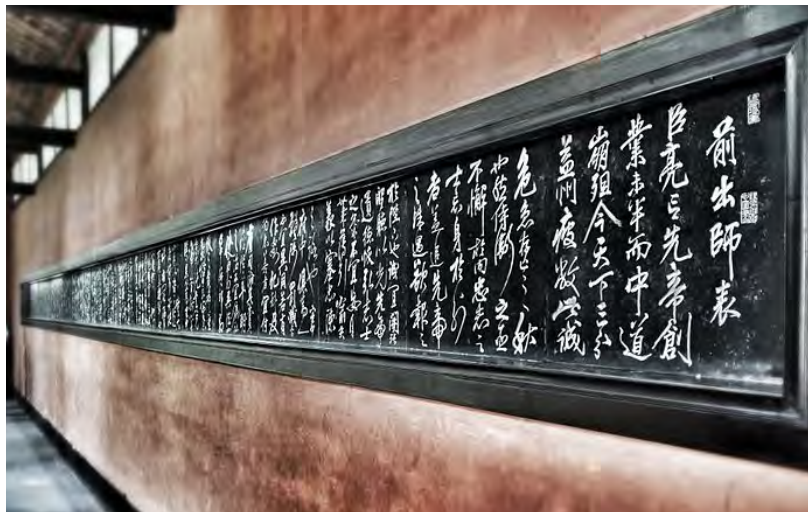

Stone carving of the First Memorial on the Northern Expedition 前出師表, written by Zhuge Liang, calligraphy by Yue Fei 岳飛 (1103-1142 CE) at the Chengdu Wu Hou Shrine 成都武候祠

Source: 蒋亦昫, Wikimedia
Tian Han 田漢 (1898-1968), a revolutionary Chinese playwright and lyricist, composed the lyrics for 'March of the Volunteers' for the music of a film, the Japanese had invaded the People's Republic of China (PRC). The lyrics declared that 'China faces her greatest peril' 中華民族到了最危險的 時候, using the phrase weixian 危險 ('crisis' plus 'peril'). The 'March of the Volunteers' later became the national anthem of China. In the Korean War of the early 1950s, Mao Zedong 毛泽东 framed China's decision to aid North Korea in these terms: 'With lips gone, teeth are exposed to cold. With the door smashed, the hall would be in danger [wei].’唇亡齒寒, 戶破堂危.

These days, wei is used as a reminder not to forget the danger and difficulties of earlier times. In 2017, President Xi Jinping 习近平 told the Politburo that, even when there is political and economic stability, people should be prepared for danger, quoting the ancient Book of Divination or I Ching 易經:

When resting in safety, do not overlook the possibility of danger [wei] ; when all seems stable do not overlook that ruin may happen; when all is in a state of order, do not overlook that chaos may erupt. 安而不忘危, 存而不忘亡, 治而不 忘亂.

Today, wei is commonly combined with $j i$ 機 'opportunity' to refer to crisis 危機, or 危机 in simplified characters. Describing the global COVID-19 pandemic, weiji could be seen to express both crisis and hope. 
This text is taken from China Story Yearbook: Crisis, edited by Jane Golley and Linda Jaivin with Sharon Strange, published 2021 by ANU Press, The Australian National University, Canberra, Australia.

doi.org/10.22459/CSY.2021.00A 